\section{PHYSICS AND CHEMISTRY OF SOLID STATE \\ V.21, No.2 (2020) pp. 332-337}

DOI: 10.15330/pcss.21.2.332-337
Vasyl Stefanyk Precarpathian

National University

ФІЗИКА І ХІМІЯ ТВЕРДОГО ТІЛА

Т. 21, № 2 (2020) C. 332-337

\author{
I.I. Gab ${ }^{1}$, T.V. Stetsyuk ${ }^{1}$, D.B. Shakhnin ${ }^{2}$
}

\title{
Influence of Vacuum Annealing on the Dispersion of Thin Double Niobium-Copper Films Deposited onto Oxide Materials
}

\author{
${ }^{1}$ Frantsevich Institute for Materials Science Problems of NAS of Ukraine, Kyiv, Ukraine, gab@ipms.kiev.ua \\ ${ }^{2}$ University "Ukraine", Kyiv, Ukraine, shakhnin@ukr.net
}

\begin{abstract}
The kinetics of dispersion of thin niobium-copper films deposited onto leucosapphire, alumina and zirconia ceramics and annealed in vacuum at temperatures up to $1100{ }^{\circ} \mathrm{C}$ with different exposition times at each temperature (from 5 up to $20 \mathrm{~min}$ ) was studied. The double films consisted of two layers: the first metallization layer was $150 \mathrm{~nm}$ niobium nanofilm deposited onto the oxide surface, and the second copper layer $1.5 \mu \mathrm{m}$ thick deposited over the first one as a solder was used for joining of metallized oxide samples. It was found that these films remain rather dense during heating up to $1050{ }^{\circ} \mathrm{C}$; and after annealing at $1100{ }^{\circ} \mathrm{C}$ they decompose into individual fragments covering about $80 \%$ the area of the ceramic substrates even after annealing during $20 \mathrm{~min}$. The kinetic curves for the dispersion of these films were plotted.
\end{abstract}

Key words: kinetics, dispersion, niobium-copper film, oxide materials.

Received 15 April 2020; Accepted 15 June 2020.

\section{Introduction}

Joining ceramic materials with each other and with metals is carried out by two main methods:

1) brazing with molten metallic solders [1-3];

2) solid-phase pressure welding [4-6].

Since ceramic materials, particularly oxide ones, are usually poorly wetted by molten metals, metal coatings are often used applied in various ways (electron beam sputtering, magnetron sputtering, chemical deposition etc.). Adhesive-active metals such as titanium, chromium, niobium and others are the most commonly used to make such coatings. Then, thus metallized ceramic parts are brazed in vacuum or an inert medium (argon, helium etc.) by molten metallic solders on the basis of tin, silver, copper, nickel etc. In this case, the thickness of the solder seam is from $50-100 \mu \mathrm{m}$ up to several millimeters. Sometimes, multilayer metal coatings are used, but the thickness of the layers and brazed seams remains high [7-9].

At the same time, there is information that the reduction in the thickness of the brazed seam leads to a significant increase in the strength of the brazed joint [10-12]. Obtaining brazed or welded joints of metallized ceramics is possible through reducing the thickness of both the metallization coating on the ceramics and the brazing layer by itself. This can be achieved if the soldering metal or alloy is also applied in the form of a rather thin film, the thickness of which does not exceed several $\mu \mathrm{m}$. In addition, a thin soldering seam allows you to obtain precision welded or brazed ceramic and ceramic-metal units which can be used in microelectronics, radio engineering, microwave engineering etc.

This objective can be achieved by application onto the ceramic surfaces of double metal films, one of which is $100-200 \mathrm{~nm}$ thick and consists of an adhesion-active metal such as $\mathrm{Ti}, \mathrm{Cr}$ etc., and the other is slightly thicker $(2-3 \mu \mathrm{m})$ and serves as a solder, e.g. $\mathrm{Cu}, \mathrm{Ag}$ etc., which will ensure joining of metallized ceramic materials during brazing or welding with fine $(2-4 \mu \mathrm{m}$ thick) solder seam.

In literature there is information on the use of twoand multilayer metal coatings in production of aircrafts, in structures to be implanted into the human body, in devices for flat displays, light-emitting devices and solar panels, in friction units, as sensitive elements of strain gauges, in erosion-resistant coatings of blades for 
engines of various purposes, as coatings for cutting tools and machine parts [13-18].

The structure of such two- or multiphase coatings, determination of the optimal ratio of the thickness of each layer, processes of interaction at the phases interface, including the ceramic phase, is also an important area of research.

The study of two-layer niobium-copper coatings (films) on oxide materials during annealing in vacuum and the creation of brazed and welded oxide ceramics joints based on them with super-thin brazed seam, the thickness of which does not exceed $5 \mu \mathrm{m}$, is the main task of the present work.

\section{Materials and Experimental Procedure}

In this paper an electron-beam method for sputtering of metal nanofilms was used.

The thickness of the deposited nanofilms was measured by two methods:

1) the metal of the given weight (calculated for films of the required thickness) is completely evaporated, then the thickness of the film can be easily calculated according to the law of Lambert [19, 20];

2) with the help of a special quartz sensor located in the vacuum sputtering chamber near the sample on which the film is deposited.

Solid non-metallic substrates were made of leucosapphire, alumina and zirconia ceramics as small thin plates $4 \times 3 \times 2 \mathrm{~mm}$ in size. One of the flat surfaces of each specimen was well polished to a roughness $R_{z}=$ $0.03 \div 0.05 \mu \mathrm{m}$. After polishing, all specimens were thoroughly defatted and burned in air at $1100{ }^{\circ} \mathrm{C}$ for one hour.

As a metal deposited directly onto non-metallic surfaces, niobium was used. Metallized samples were then coated by copper films serving as a solder when joining the samples.

The quality of all applied nanofilms was controlled using a XJL-17 metallographic microscope.

The specimens with deposited onto them metal films were annealed in a vacuum chamber for various periods of time (from 5 up to $20 \mathrm{~min}$ ) and at different temperatures (from $900^{\circ} \mathrm{C}$ up to $1100^{\circ} \mathrm{C}$ ) in the vacuum not less than $2 \times 10^{-3} \mathrm{~Pa}$.

Annealed specimens were investigated using scanning electron microscopes JSM-6700 F and Superprobe 733 with microphotographs storing. Using these microphotographs, the areas of metal islets on the surface of non-metallic samples were determined by the planimetric method, i.e. by weighing the elements of the metallized surfaces of samples carved out from the paper microphotograph copy [11]. The experimental data obtained were processed in the form of graphs showing the dependence of the surface area of the samples covered with metal nanofilms on the annealing parameters (temperature, time).

\section{Results and Discussion}

The thickness of the metallization layer of niobium at the leucosapphire, alumina, and zirconia ceramics substrates was $150 \mathrm{~nm}$, and the copper layer thickness was $1.5 \mu \mathrm{m}$.

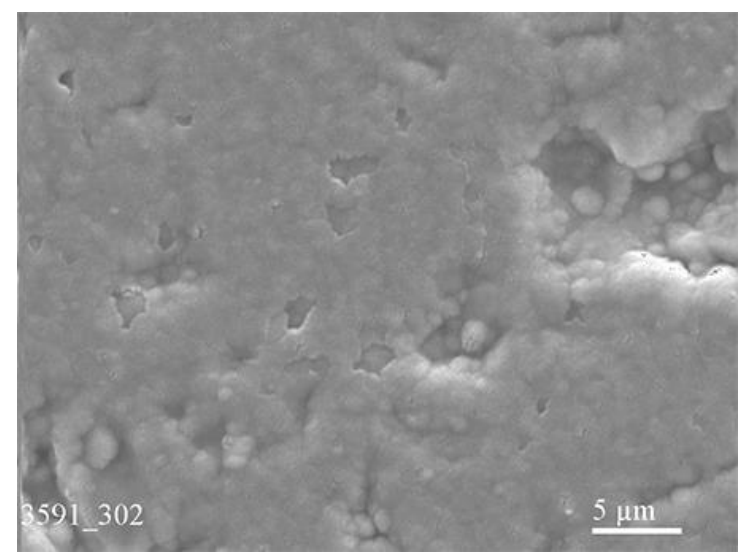

$\mathbf{a}$

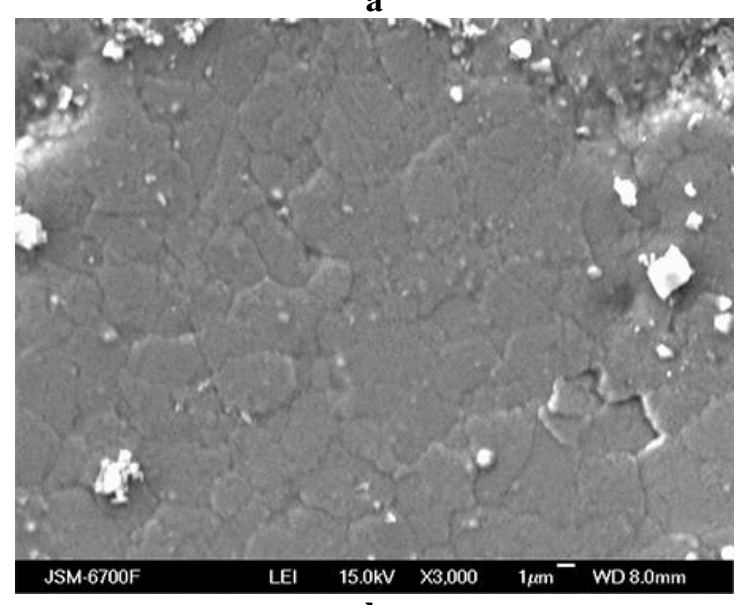

b

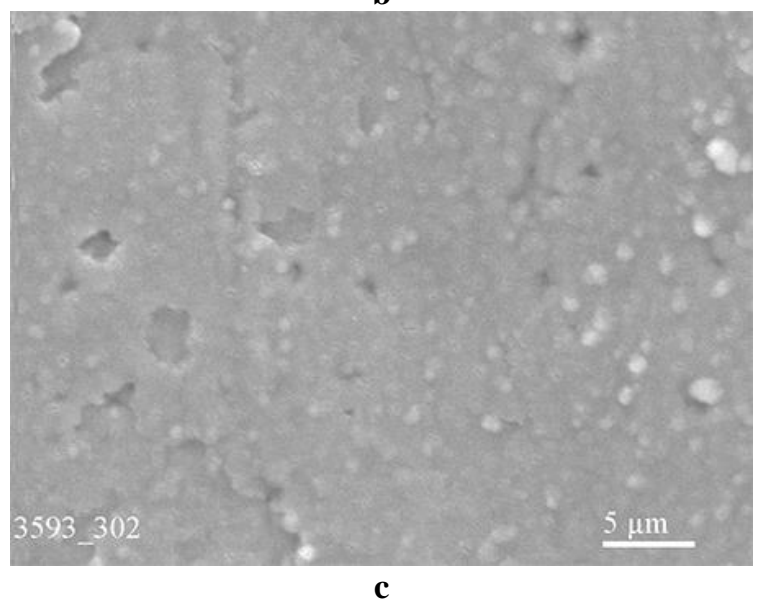

Fig. 1. SEM image of double niobium-copper film deposited onto oxide materials and further annealed at $900{ }^{\circ} \mathrm{C}$ during $20 \mathrm{~min}$ in vacuum, x3000: a - alumina ceramics; b - leucosapphire; $\mathrm{c}$ - zirconia ceramics.

The integrity of the original niobium-copper films at the leucosapphire, alumina, and zirconia ceramics was intact even after annealing at $900{ }^{\circ} \mathrm{C}$ for ten minutes. The first slight changes in them appeared only after twenty minutes at this temperature (Fig. 1). The situation did not change virtually with increase of the annealing 


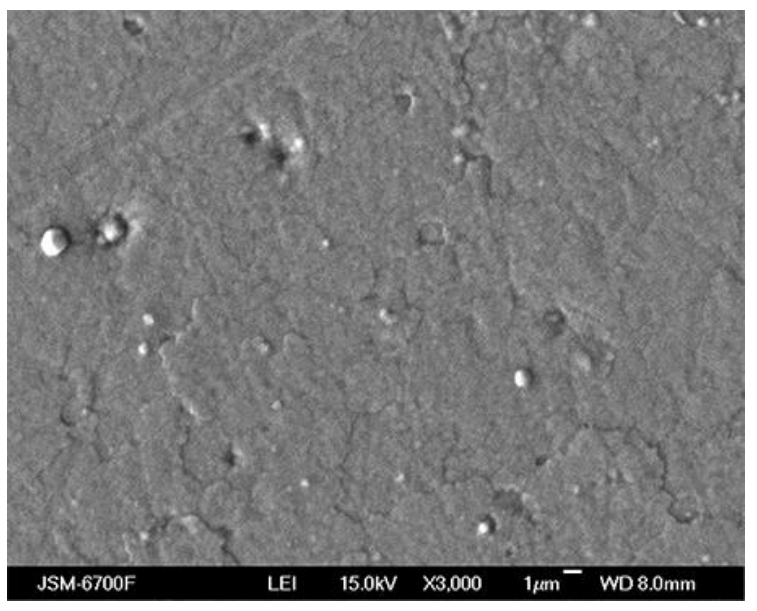

a

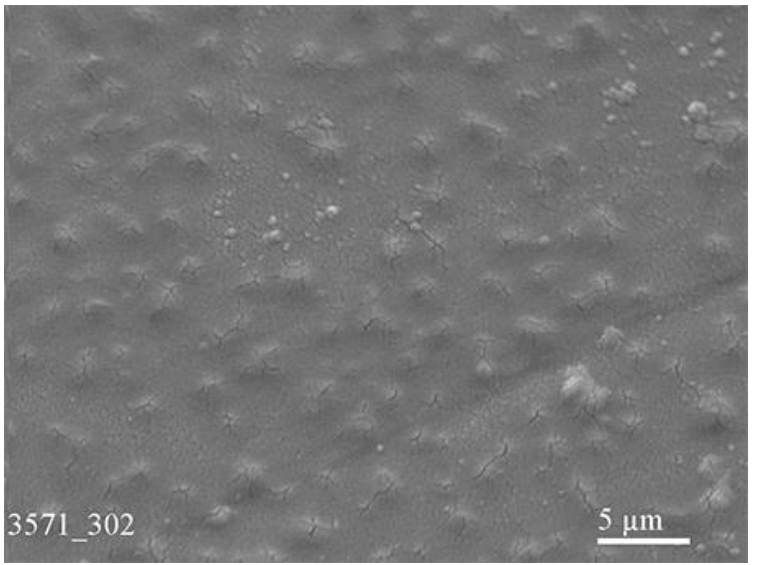

b

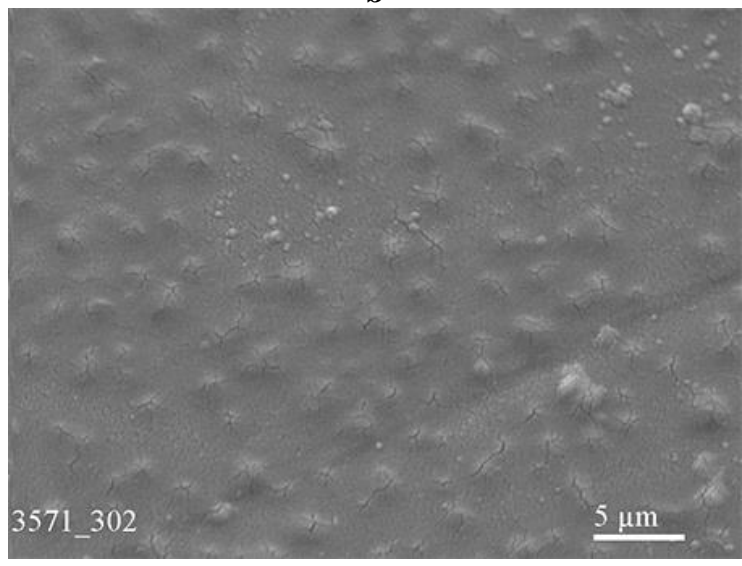

c

Fig. 2. SEM image of double niobium-copper film deposited onto oxide materials and further annealed at $1000{ }^{\circ} \mathrm{C}$ during $20 \mathrm{~min}$ in vacuum, x3000: a - alumina ceramics; $\mathrm{b}$ - leucosapphire; $\mathrm{c}$ - zirconia ceramics.

temperature up to $1000^{\circ} \mathrm{C}$, at which noticeable changes in the films morphology were found also after twenty minutes of exposition (Fig. 2). Raising the annealing temperature up to $1050^{\circ} \mathrm{C}$ intensified the process of changing the films morphology, which was noticeable already after ten minutes of exposition. After twenty minutes of annealing, there was a noticeable tendency for the dispersion in the films (Fig. 3), although they were still covering even more than $80 \%$ of the substrate surface. Significant dispersion of the films was caused only by annealing at $1100^{\circ} \mathrm{C}$, when the copper had to be already in molten state, which is clearly visible after five minutes of exposition.

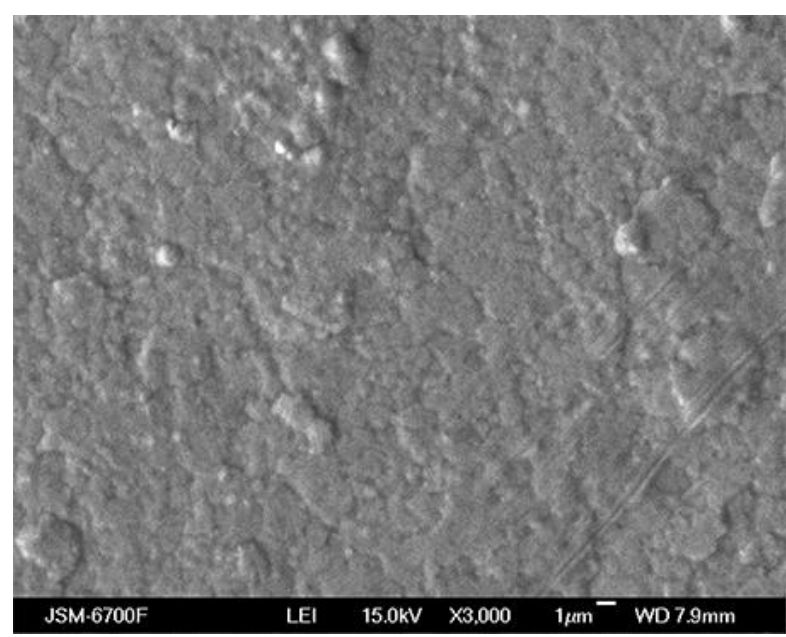

a

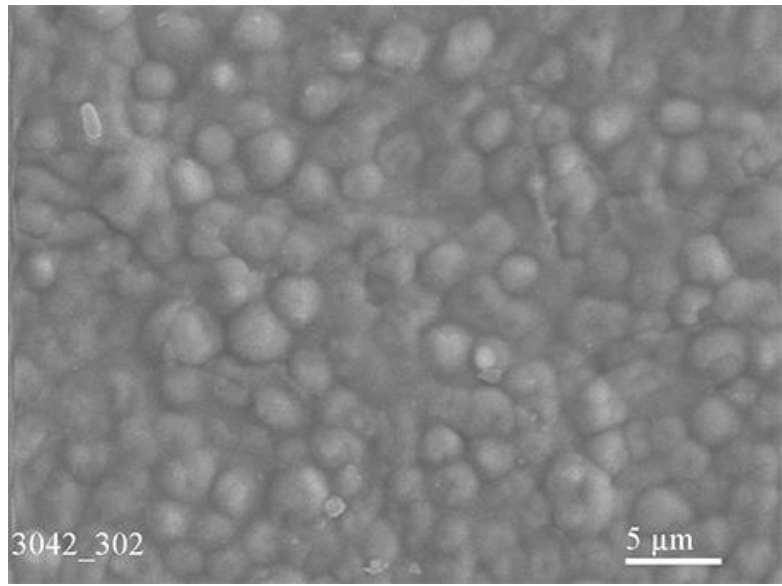

b

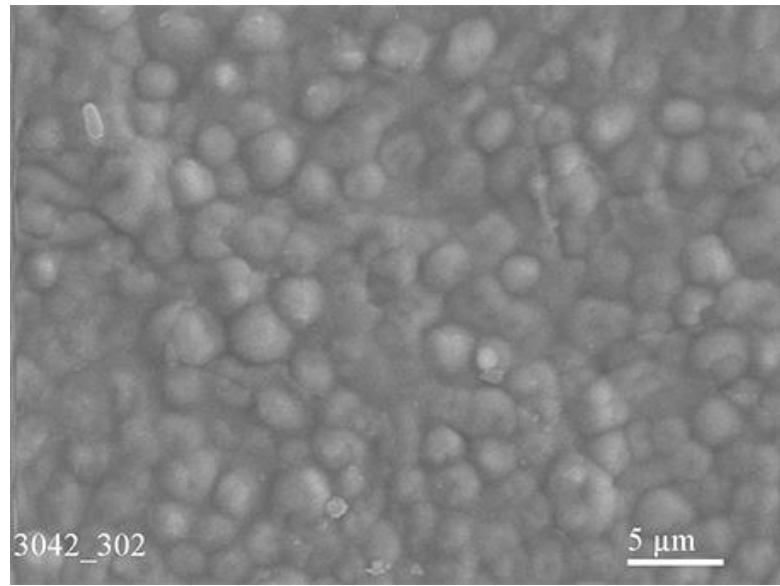

Fig. 3. SEM image of double niobium-copper film deposited onto oxide materials and further annealed at $1050{ }^{\circ} \mathrm{C}$ during $20 \mathrm{~min}$ in vacuum, x3000: a - alumina ceramics; $\mathrm{b}$ - leucosapphire; $\mathrm{c}$ - zirconia ceramics.

After ten minutes of exposition, and especially after twenty minutes of annealing, the films were strongly dispersed (Fig. 4), although their residues were still covering more than $70 \%$ of the substrates surface area. 


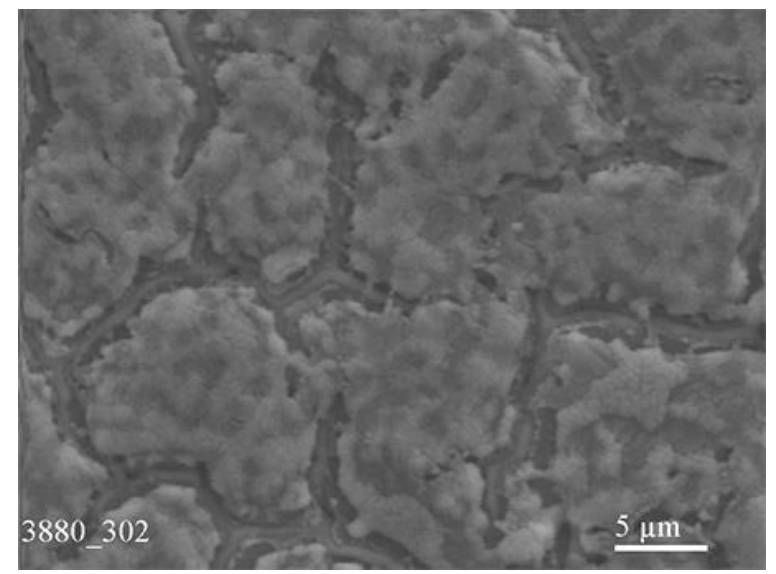

$\mathbf{a}$

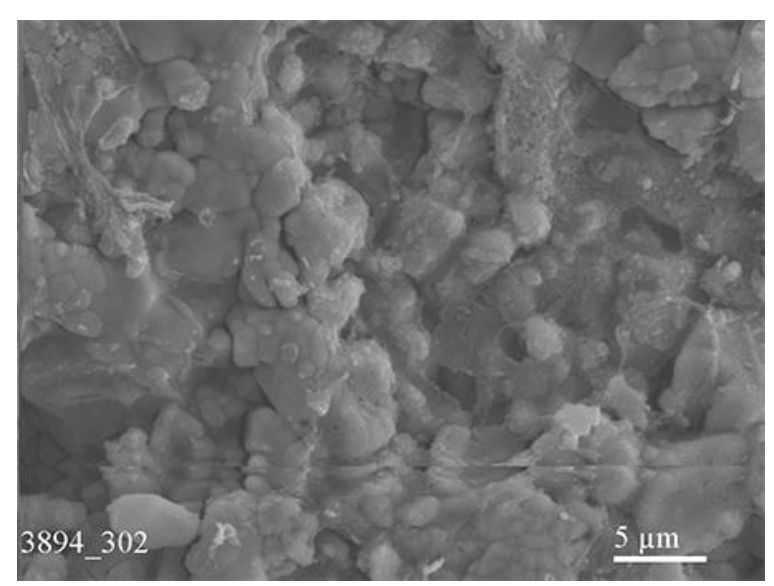

b

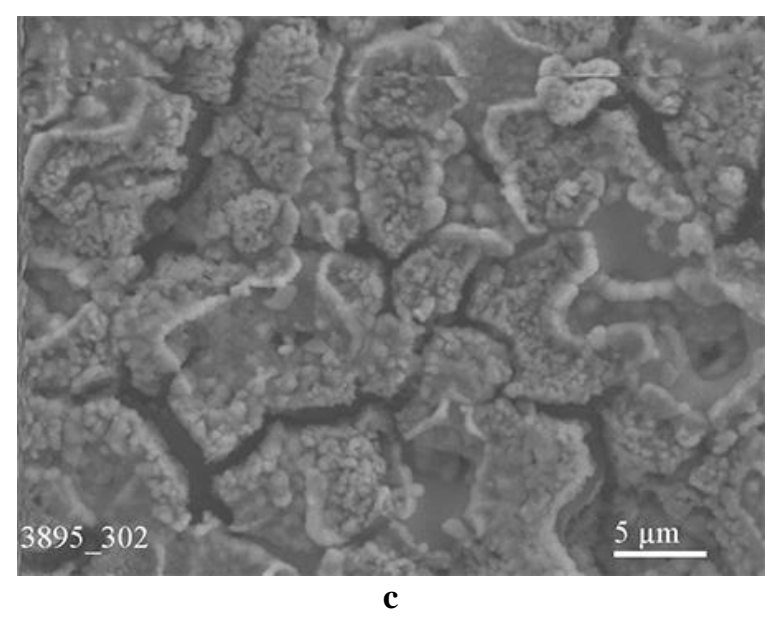

Fig. 4. SEM image of double niobium-copper film deposited onto oxide materials and further annealed at $1100{ }^{\circ} \mathrm{C}$ during $20 \mathrm{~min}$ in vacuum, $\mathrm{x} 3000$ : a - alumina ceramics; $\mathrm{b}$ - leucosapphire; $\mathrm{c}$ - zirconia ceramics.

Fig. 5 shows kinetic dispersion curves of copper films at leucosaphyre, alumina, and dioxidocircle ceramics surfaces metallized with niobium nanoparticles and annealed in vacuum at temperatures $900-1100{ }^{\circ} \mathrm{C}$ during different exposition times.

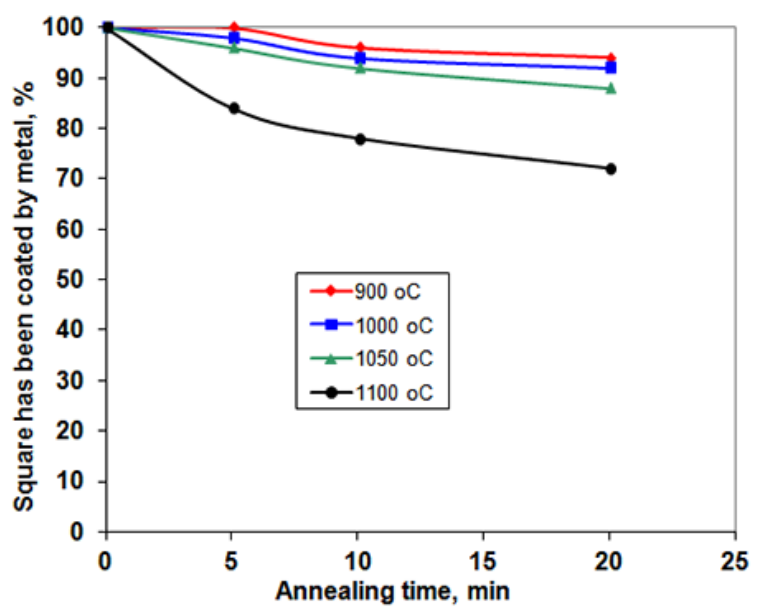

a

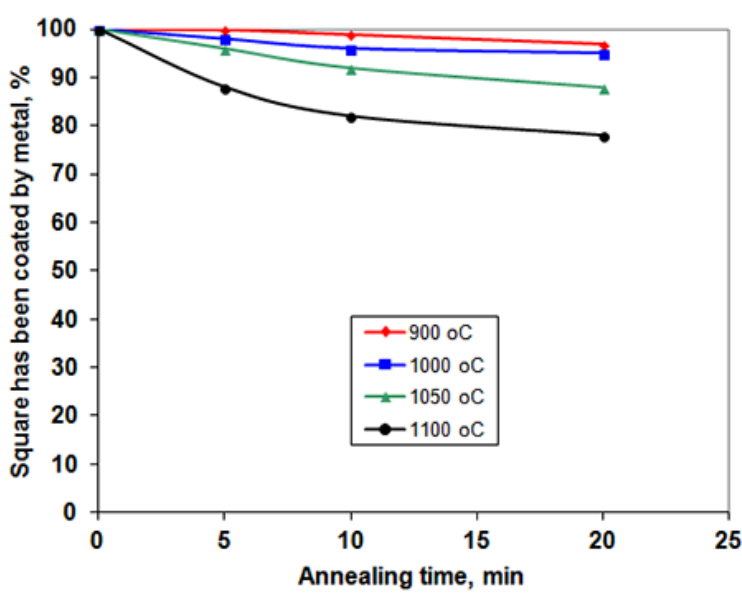

b

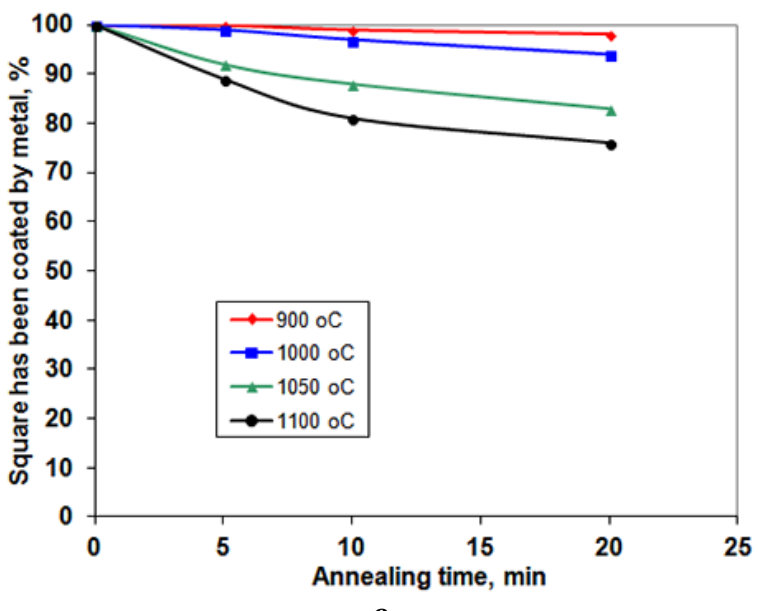

Fig. 5. Dependence of oxide materials area covered by double niobium-copper film on annealing time at various temperatures $\left(900-1100{ }^{\circ} \mathrm{C}\right)$ : a - alumina ceramics; b leucosapphire; $\mathrm{c}$ - zirconia ceramics.

\section{Conclusions}

According to the study results, the dispersion during annealing in vacuum of double niobium-copper films at all three oxides surfaces is practically the same, and all these films have good adhesion to the oxide substrates covering almost $90 \%$ of the substrate area after twenty 
minutes of annealing at $1050{ }^{\circ} \mathrm{C}$. Even after annealing at $1100{ }^{\circ} \mathrm{C}$, copper film fragments are covering about $80 \%$ of the substrate area. This makes it possible to recommend these double films for further joining of all three studied oxide substrates by pressure welding or brazing.

The kinetic curves of dispersion during annealing of double niobium-copper films on leucosapphire, alumina and zirconia ceramics were plotted, using which it is possible to determine the basic technological parameters (temperature and exposition time at this temperature) of the processes of joining of ceramic materials by brazing or pressure welding. According to these plots, it can be concluded that the most suitable method for joining the samples metallized with studied films is pressure welding allowing the joining process to be carried out at $900 \div$ $1050^{\circ} \mathrm{C}$ when the film is still sufficiently continuous.

According to the data obtained, it is also possible to join oxide materials using dual niobium-copper films by brazing at a temperature $1100{ }^{\circ} \mathrm{C}$, i.e. when the copper film is molten. Using both of these methods, brazed ceramics joints with a seam thickness not exceeding 5 microns were obtained having shear strength $150 \mathrm{MPa}$.

Gab I.I. - candidate of science (tech.), senior research fellow, leading researcher;

Stesyuk T.V. - researcher;

Shakhnin D.B. - candidate of chemical sciences, associate professor.

[1] M.A. Rubashev, G.I. Berdov, V.N. Gavrilov, M.L. Lyubimov et all, Termostoykiye dielektriki i ikh spai s metallami v novoy tekhnike (Atomizdat, Moskva, 1980).

[2] Yu.V. Naidich, Kontaktnyye yavleniya v metallicheskikh rasplavakh (Naukova dumka, Kiev, 1972).

[3] N.F. Lashko, S.V. Lashko, Payka metallov (Mashinostroyeniye, Moskva, 1967).

[4] N.F. Kazakov, Diffuzionnaya svarka materialov (Mashinostroyeniye, Moskva, 1976).

[5] V.A. Bachin, Teoriya, tekhnologiya i oborudovaniye diffuzionnoy svarki (Mashinostroyeniye, Moskva, 1991).

[6] I.I. Metelkin, M.A. Pavlova, N.V. Pozdeyeva, Svarka keramiki s metallami (Metallurgiya, Moskva, 1977).

[7] V.R. Yevdokimov, S.L. Kashtanov, L.N. Lado, S.N. Shubin, Svarochnoye proizvodstvo 8, 2 (1995).

[8] M. Sirakane, M. Nakakhasi, T. Yamadzaki, Zayavka 60-239373, Yaponiya Zayavl. 15.05.84. Opubl. 28.11.85.

[9] M. Namura, Y. Ito, K. Kaneya, Zayavka № 380163 Yaponiya. Zayavl. 21.08.89. Opubl. 04.04.91.

[10] Yu. Naidich, Industrial Ceramics 19(3), 162 (1999).

[11] Yu.V. Naidych, Y.Y. Gab, B.D. Kostyuk, T.V. Stetsyuk, D.Y. Kurkova, S.V. Dukarov, Dopovidi Natsionalnoi akademii nauk Ukrainy 35, 97 (2007).

[12] Yu.V. Naidych, Y.Y. Gab, B.D. Kostyuk, T.V. Stetsyuk, D.Y. Kurkova, S.V. Dukarov, Tekhnika mashinostroyeniya 1, 28 (2006).

[13] V.M. Yakovich, V.M. Komarovskaya, Inzhenerno-pedagogicheskoye obrazovaniye v XXI veke: materialy XII Respublikanskoy nauchno-prakticheskoy konferentsii molodykh uchenykh i studentov BNTU (BNTU, Minsk, 2016), p. 215.

[14] A.A. Andreyev, G.I. Kostyuk, N.A. Minayev, Aviatsionno-kosmicheskaya tekhnika i tekhnologiya 89(2), 28 (2012).

[15] S.V. Zaytsev, Yu.V. Gerasimenko, M.V. Lobanov, A.M. Khoviv, Kondensirovannyye sredy i mezhfaznyye granitsy 16(2), 153 (2014).

[16] T.A. Lobanova, A.O. Volkhonskiy, I.V. Blinkov, Innovatika i ekspertiza 10(1), 76 (2013).

[17] D.V. Velikodnyy, C.I. Protsenko, I.Ye. Protsenko, FIP 6(1-2), 37 (2008).

[18] M. Naveed, A. Obrosov, S. Weib, Hindawi Publishing Corporation Conference Papers in Science Volume, ID 873543 (2015) (http://dx.doi.org/10.1155/2015/873543).

[19] S. Metfessel, Tonkie plenki, ih izgotovlenie i izmerenie (Gosenergoizdat, Moskva-Leningrad, 1963).

[20] G. Khaas, R.E. Tun, Fizika tonkikh plenok (Mir, Moskva, 1968). 


\title{
I.I. Габ ${ }^{1}$, Т.В. Стецюк ${ }^{1}$, Д.Б. Шахнін ${ }^{2}$
}

\section{Вплив відпалу у вакуумі на диспергування тонких подвійних ніобісво-мідних плівок, нанесених на оксидні матеріали}

\author{
${ }^{I}$ Інститут проблем матеріалознавства ім. I. М. Францевича НАН Украйни, \\ м. Київ, Украӥна, gab@ipms.kiev.иа \\ ${ }^{1}$ Університет ,Україна”, м. Київ, Украӥна, shakhnin@ukr.net
}

\begin{abstract}
Досліджена кінетика диспергування тонких ніобієво-мідних плівок, що нанесені на лейкосапфір, алюмооксидну та диоксидноцирконієву кераміки та відпалені у вакуумі при температурах до $1100^{\circ} \mathrm{C}$ при різних термінах витримки при кожній температурі (від 5 до 20 хв). Подвійні плівки складалися 3 двох шарів: перший металізований шар являв собою ніобієву наноплівку завтовшки 150 нм, нанесену на поверхню оксиду, а на неї був нанесений мідний шар завтовшки 1,5 мкм, який мав слугувати в якості припою при з'єднанні між собою металізованих керамічних зразків. Виявлено, що ці плівки залишаються досить щільними при нагріванні їх до $1050^{\circ} \mathrm{C}$, а після відпалу при $1100^{\circ} \mathrm{C}$ розпадаються на окремі фрагменти, які вкривають близько 80 \% площі керамічних підкладок навіть після відпалу протягом 20 хв. Побудовані кінетичні криві диспергування даних плівок.
\end{abstract}

Ключові слова: кінетика, диспергування, ніобієво-мідна плівка, оксидні матеріали. 